\title{
Immune-enhancing activity of $C$. militaris fermented with Pediococcus pentosaceus (GRC-ON89A) in CY-induced immunosuppressed model
}

\author{
Ha-Kyoung Kwon, Woo-Ri Jo and Hye-Jin Park ${ }^{*}$ (1)
}

\begin{abstract}
Background: Cordyceps militaris (C. militaris) is reported to exert various immune-activities. To enhance its activity, we fermented C.militaris with Pediococcus pentosaceus ON89A (GRC-ON89A). In this study, we investigated the immune-enhancing activity GRC-ON89A, using immunosuppressed model.

Methods: Immunosuppression was induced by intraperitoneal injection of cyclophosphamide (CY). Each group was orally administered distilled water, GRC-ON89A or GRC, respectively. The phagocytic activities against lgG -opsonized FITC particles were measured using phagocytosis assay kit. The contents $\beta$-glucan, cordycepin and SCFA were measured using $\beta$-glucan kit, liquid chromatography-mass spectrometry analysis and Gas chromatography-mass spectrometry analysis, respectively.

Results: Among GRC fermented with different probiotic strains (Pediococcus pentossaceus ON89A, Lactobacillus pentosus SC64, Weissella cibaria Sal.Cla22), GRC-ON89A induced the highest elevation of nitric oxide production and enhanced phagocytic activity of RAW 264.7 cells. In primary cultured murine macrophages from normal and CY-treated mice, GRCON89A increased phagocytic activity, compared to that in control cells. GRC-ON89A also significantly induced the mRNA expression of TNF-a and IL-10 and the levels of phosphorylated Lyn, Syk and MAPK. The contents of $\beta$-glucan, cordycepin and SCFA in GRC significantly increased after ON89A fermentation, compared to those in unfermented GRC.

Conclusion: These results indicate that GRC-ON89A exerted the enhanced immunostimulatory activity and contained more nutritional components, compared to unfermented GRC. Our results suggested that GRC-ON89A may be applied as an agent for immune boosting therapy in immune suppressed patients.
\end{abstract}

Keywords: Cordyceps militaris, Probiotic fermentation, Immune enhancing, Pediococcus pentosaceus, Cyclophosphamideinduced immune suppression, macrophage

\section{Background}

The dysregulation of immune responses and systems aggravates malignancies and infectious diseases of immune surveillance, including microbial detection and host defense mechanisms [1]. Immunosuppression is a state of temporary or permanent immune dysfunction, and can increase organism vulnerability to pathogens. Immune dysfunction is caused by various factors, including aging and chemotherapeutic drugs.

* Correspondence: nimpi79@hanmail.net

Department of Food Science and Biotechnology, Gachon University, Sungnam, Gyeonggi-do 461-701, South Korea
Cyclophosphamide (CY) is a cytotoxic alkylating drug, used as a chemotherapeutic drug in childhood and adult malignancies [2]. Many cancer patients with lymphomas and leukemia were primarily treated with CY $[3,4]$. However, severe side effects were reported since the CY uptake into normal cells occurs more than in cancer cells [2]. CY induces apoptotic cell death and causes the pronounced cytotoxic effect on lymphocytes [5]. It suppresses the immune system by killing immune cells and suppressing the proliferation and phagocytic activity and Nitric oxide $(\mathrm{NO})$ production of macrophage, the activity of $\mathrm{T}$ cells and $\mathrm{B}$ cells 
$[6,7]$. Therefore, to improve immunity, many research groups have tried to develop immunomodulatory agents from traditional Oriental medicine.

Cordyceps militaris (family Clavicipitaceae, C. militaris) is a widely used traditional oriental medicine in East Asia to treat immune-dysregulated diseases such as cancer. Previous studies have reported that $C$. militaris extracts possess immune boosting properties, anti-inflammatory activities [8, 9], and anti-cancer activities against lymphoma [10], leukemia [11], bladder cancer [12], breast cancer and colorectal cancer [13]. However, it is difficult to obtain C. militaris in large amounts from nature owing to its rarity. Instead of the dead bodies of insects, our research group cultivated $C$. militaris using germinated rhynchosia nulubilis (GRC) as a culture media because they contained bioactive components. Previously, our group demonstrated that an extract prepared from $C$. militaris grown on germinated soybeans (GSC) exhibited various biological activities, including anti-allergic activities in vivo and in vitro [14, 15]. Additionally, acidic polysaccharides from GSC exerted anti-viral activity and induced macrophage phagocytic activity [16]. However, GRC is not efficient to commercially utilize due to high cost and low extraction yield after the extraction procedure. As traditional fermented food is known to exert many health effects, researchers have been trying to prove the biological properties of natural products fermented using lactic acid bacteria (LAB). LAB are gram-positive organisms found in vegetables, meats, dairy products, and many parts of the human body, including the gastrointestinal tract. Probiotics can be defined as live microbial food ingredients that exert anti-mutagenic, anticarcinogenic, and anti-inflammatory activities, reduce serum cholesterol, and modulate immune responses [17]. In addition, fermentation by LAB can enhance preservation duration, taste, flavor, texture, as well as augmenting physiological activities such as digestion efficiency and natural substance metabolism [18]. Here, GRC fermented using different probiotic strains can be used without expensive extraction procedure and exert enhanced biological activities, compared to GRC.

To the best of our knowledge, no studies have analyzed the effects of GRC-ON89A on macrophage activity and immune function in normal and CYinduced immunosuppressed mice. The main objective of this study was to investigate whether GRC fermented with Pediococcus pentosaceus has improved immunostimulatory activities compared to unfermented GRC. This is the first report demonstrating the immunostimulatory effects of GRC-ON89A in both healthy and immunosuppressed mice.

\section{Methods}

\section{Chemicals and reagents}

DMEM, fetal bovine serum (FBS) (Gibco/invitrogen, Carlsbad, CA, USA), a Cell Counting Kit-8 assay (Dojindo Lab, Kumamoto, Japan), $\beta$-glucan kit (Megazyme International, Wicklow, Ireland), Phagocytosis Assay Kit (Cayman, MI, USA), cyclophosphamide (Sigma Aldrich, St.Louis, MO, USA) $\beta$-1,3-glucan (Sigma Aldrich, St.Louis, MO, USA) and cordycepin (Sigma Aldrich, St.Louis, MO, USA) were purchased. Phospho-Lyn antibody, Lyn antibody, phospho-Syk antibody, Syk antibody, phospho-ERK antibody, ERK antibody, phospho-p38 antibody, p38 antibody, phospho-JNK antibody, JNK antibody, NFKB antibody, phospho-IKB antibody and IKB antibody were obtained from Cell signaling Technology Inc. (Danvers, MA, USA). $\beta$-Actin antibody was obtained from Santa Cruz (Dallas, TX, USA).

\section{Preparation of GRC fermented with probiotic strains} The extract of $C$. militaris grown on GRC is prepared using patented technologies developed by Cell Activation Research Institution (CARI, Seoul, Korea), where a voucher specimen was deposited (Kucari: 0903). Pediococcus pentosaceus ON89A isolated from onion, Lactobacillus pentosus SC64 isolated from pickled burdock, and Weissella cibaria Sal.Cla22 isolated from salted clam strains used in this study were obtained from Dr. YS Park. GRC $(5 \% w / v)$ was extracted with distilled water (D.W) at $105{ }^{\circ} \mathrm{C}$ for $2 \mathrm{~h}$ and then cultured with the indicated probiotic strains for $24 \mathrm{~h}$. GRC-inoculated probiotics were heat-killed at $100{ }^{\circ} \mathrm{C}$ for $10 \mathrm{~min}$ and sonicated for $3 \mathrm{~min}$ (Sonics \& Materials, Inc., WA, USA) [19].

\section{Cell cultures}

The RAW 264.7 murine macrophage cell line was obtained from the American Type Culture Collection (ATCC, Manassas, VA, USA) and cultured in DMEM with $100 \mathrm{U} / \mathrm{ml}$ penicillin and streptomycin. The cells were grown in a $100 \mathrm{~mm}$ dish culture at $37{ }^{\circ} \mathrm{C}$ with $5 \%$ $\mathrm{CO}_{2}$ in a humidified atmospheric pressure chamber.

\section{Quantification of nitric oxide (NO)}

Both RAW 264.7 cells and primary cultured peritoneal macrophages were seeded in 96-well plates $\left(2 \times 10^{5}\right.$ cells/ well) and then stimulated with various concentrations of the indicated samples (GRC-SC64 (voucher specimen number Gaucari: 0802), GRC-ON89A (voucher specimen number Gaucari: 0801), Sal.Cla22 (voucher specimen number Gaucari: 0803)). After $48 \mathrm{~h}$, the culture supernatants were collected, and NO concentrations were measured using griess reagent. Equal volumes of Griess reagent ( $1 \%$ sulfanilamide, $0.1 \%$ naphthylenediamine dihydrochloride, and $0.5 \%$ phosphoric acid) and the sample were incubated together at room temperature for $10 \mathrm{~min}$. 
The absorbance at $540 \mathrm{~nm}$ was measured using a microplate reader (Epoch, Biotek Instruments, INC., VT, USA) as described previously [20].

\section{Cell proliferation assay}

RAW264.7 cell proliferation was measured using the Cell Counting Kit-8 (CCK-8) assay (DOJINDO Laboratories, Kumamoto, Japan). RAW264.7 cells were plated onto 96-well plate $\left(1 \times 10^{4}\right.$ cells/well $)$ and then treated with indicated samples (SC64, ON89A, sal.cla22) for 48 h. Peritoneal macrophages were harvested from GRC-ON89A-treated BALB/c mice as described previously [21] and were resuspended in RPMI 1640 (containing 10\% FBS) media, then plated into 96-well culture plates $\left(2 \times 10^{5}\right.$ cells/well). They were incubated with a CCK-8, solution for $4 \mathrm{~h}$ at $37{ }^{\circ} \mathrm{C}$ under $5 \% \mathrm{CO}_{2}$. After adding CCK-8 solutions, cell proliferation was measured using a microplate reader at $450 \mathrm{~nm}$ (Epoch, Biotek Instruments, INC, Winooski, VT, USA). Data were expressed as a percentage relative to proliferation of control cells.

\section{Animals}

Female 6- to 8-week-old BALB/c mice with body weights of $18 \pm 2 \mathrm{~g}$ were obtained from Daehanbiolink Co., Ltd. (Seoul, Korea). The animals were acclimatized to laboratory conditions for 7 days prior to the commencement of experimentation. The mice were maintained under constant conditions (temperature: 22 $\pm 2{ }^{\circ} \mathrm{C}$, humidity: 40-60\%, light/dark cycle: $12 \mathrm{~h}$ ) and allowed free access to water and food. All of the animal experiments were performed in accordance to the instructions of the Medical Ethics Committee for the Use of Experimental Animals at Gachon University (GIACUC-R2015014).

\section{Experimental design}

Animal experiments were performed in both normal and immunosuppressed murine models. For animal experiments using normal mice, mice were randomly divided into three groups ( $>10$ mice per group): normal control group (Control), GRC-ON89A-treated groups (GRC-ON89A) and GRC-treated groups (GRC). For animal experiments using immunosuppressed mice, mice were randomly dived into three groups ( $>10$ mice per group): CY-injected control (Control-CY), CY-injected and GRC-ON89A-treated groups (GRC-ON89A-CY), and CY-injected and GRC-treated groups (GRC-CY). Immunosuppression was induced by intraperitoneal injection of CY $(80 \mathrm{mg} / \mathrm{kg})$ once per day for the initial and final 3 consecutive days. From day 1 to 10 or 19 , the four different groups of mice were orally administered D.W, GRC-ON89A, or GRC daily at doses of heatinactivated $1.0 \times 10^{8} \mathrm{CFU} / \mathrm{ml} /$ mouse. Twenty-four hours after the final administration, mice were weighed and sacrificed. Mice were euthanized by injecting $1.5 \%$ tribromoethanol in tert-amyl alcohol intraperitoneally (Avertin, Sigma Aldrich, MO, USA). The spleen and thymus were immediately removed and weighed. A schematic of the experimental design is shown in Fig. 3a and Fig. 4a. The splenic and thymic indices were calculated as the spleen and thymus weight/body weight, respectively.

\section{Isolation of primary cultured peritoneal macrophages}

Peritoneal macrophages were obtained according to previously described methods [21]. Briefly, the mice were sacrificed to harvested peritoneal macrophages. The mice were sacrificed and $5 \mathrm{~mL}$ of PBS was injected intraperitoneally. After massaging the abdomen gently for $3 \mathrm{~min}$, the peritoneal fluid was extracted and centrifuged at $1500 \mathrm{rpm}$ for $10 \mathrm{~min}$. The cell pellets were then suspended in RPMI1640 (supplemented with $10 \% \mathrm{FBS}, 100 \mathrm{U} / \mathrm{ml}$ penicillin and $100 \mathrm{U} / \mathrm{ml}$ streptomycin), seeded in plates at a density of $2 \times 10^{5}$ cells $/ \mathrm{ml}$, and allowed to adhere for $4 \mathrm{~h}$ at $37{ }^{\circ} \mathrm{C}$ in a humidified incubator containing $5 \% \mathrm{CO}_{2}$. After $4 \mathrm{~h}$ incubation, non-adherent cells were removed by washing twice with PBS and freshly prepared medium was added.

\section{Phagocytic activity of peritoneal macrophages and RAW 264.7 cells}

Isolated peritoneal macrophages $\left(5 \times 10^{4}\right.$ cells per well) and RAW 264.7 cells $\left(2 \times 10^{5}\right.$ cells per well) were plated in 96-well plates and incubated for $24 \mathrm{~h}$ in a humidified atmosphere with $5 \% \mathrm{CO}_{2}$ at $37{ }^{\circ} \mathrm{C}$. GRC and GRCON89A were treated for 24-48 h. Phagocytosis activity was evaluated using Cayman Phagocytosis Assay Kit (Cayman, MI, USA). Following manufacturer's instructions, latex bead-rabbit IgG-FITC complexes were added directly to pre-warmed culture medium to a final dilution of 200:1. The images (magnification, 100×) were obtained every $2 \mathrm{~h}$ for $48 \mathrm{~h}$ (Nikon ECLIPSE Ti, Tokyo, Japan). The degree of phagocytic activity was measured by analyzing obtained images using MetaMorph software version 7.8.9.0 (Molecular Devices, Sunnyvale, USA). Image analysis was performed using the NIH Image J software (Wright Cell Imaging Facility) and spot counting was done to quantify the number of phagocytized particle signals per cell [22].

RNA isolation, CDNA synthesis, and reverse transcriptionpolymerase chain reaction (RT-PCR)

RT-PCR was performed as previously described [23]. RNA was extracted using TRIzol Reagent (Life Technologies, Washington, USA). The concentration and quality of the RNA was detected using Take3 
Micro-Volume Plates (Epoch, Biotek Instruments, INC, VT, USA). cDNA synthesis reactions and RT-PCR were performed according to the manufacturer's instructions (First Strand cDNA Synthesis Kit, Vilnius, Lithuania) and normalized against the expression of glyceraldehyde 3-phosphate dehydrogenase (GAPDH) as a housekeeping gene. Total RNA was isolated from serum, tissue, and cultured RAW 264.7 cells. The following primers were used in this study: GAPDH, 5'-GCA AAG TGG AGA TTG TTG CCA TC-3' (forward) and 5'-CAT ATT TCT CGT GGT TCA CAC CC-3' (reverse); TNF$\alpha$ 5'-ATG AGC ACA GAA AGC ATG ATC CG-3' (forward) and $5^{\prime}$-CCA AAG TAG ACC TGC CCG GAC TC-3' (reverse); IL-10 5'-TGC TAT GCT GCC TGC TCT TA-3' (forward) and 5'-GGC AAC CCA AGT AAC CCT TA-3' (reverse). The PCR program for GAPDH was as follows: initial denaturation at $94{ }^{\circ} \mathrm{C}$ for 2 min, followed by 30 cycles of denaturation at $94{ }^{\circ} \mathrm{C}$ for $20 \mathrm{~s}$, annealing at $58.4{ }^{\circ} \mathrm{C}$ for $10 \mathrm{~s}$, and extension at $72^{\circ}$ $\mathrm{C}$ for $30 \mathrm{~s}$, with a final extension at $72{ }^{\circ} \mathrm{C}$ for $5 \mathrm{~min}$. The PCR program for TNF- $\alpha$ was as follows: initial denaturation at $94{ }^{\circ} \mathrm{C}$ for $2 \mathrm{~min}$, followed by 30 cycles of denaturation at $94{ }^{\circ} \mathrm{C}$ for $20 \mathrm{~s}$, annealing at $60^{\circ} \mathrm{C}$ for $10 \mathrm{~s}$, and extension at $72{ }^{\circ} \mathrm{C}$ for $45 \mathrm{~s}$, with a final extension at $72{ }^{\circ} \mathrm{C}$ for $5 \mathrm{~min}$. The PCR program for IL-10 was as follows: initial denaturation at $94{ }^{\circ} \mathrm{C}$ for $2 \mathrm{~min}$, followed by 30 cycles of denaturation at $94{ }^{\circ} \mathrm{C}$ for $20 \mathrm{~s}$, annealing at $55.4{ }^{\circ} \mathrm{C}$ for $10 \mathrm{~s}$, and extension at $72{ }^{\circ} \mathrm{C}$ for $40 \mathrm{~s}$, with a final extension at $72{ }^{\circ} \mathrm{C}$ for $5 \mathrm{~min}$.

\section{Western blotting analysis}

Western blotting analysis was performed as described previously [20]. Protein concentrations were determined using Pierce BCA (Bicinchoninate) Protein Assay Kit (Thermo SCIENTIFIC, Meridian, Rockford, USA). Total protein was separated using SDS PAGE on a $10 \%$ polyacrylamide gel, followed by electrophoretic transfer onto nitrocellulose membranes (Bio-Rad Laboratories, Inc., Hercules, CA, USA). The membranes were incubated with $5 \%$ skim milk solution, followed by incubation with a primary antibody. The membranes were washed in a 1 $\mathrm{x}$ TBST $(20 \mathrm{mM}$ Tris, $500 \mathrm{mM}$ sodium chloride, $\mathrm{pH}$ 7.6, and $0.1 \%$ Tween 20 ) buffer and incubated with horseradish peroxidase-conjugated secondary antibodies (Santa Cruz, CA, USA) for 1-2 h. The immunoreactive bands were detected using the enhanced chemi-luminescence western blotting detection system by odyssey LCI Image software (LI-COR Biosciences, Lincoln, NE, USA).

\section{$\beta$-glucan content}

The $\beta$-glucan content in GRC and GRC-ON89A was determined using mushroom and yeast specific $\beta$-glucan kit as the manufacturer's protocols. The absorbance of all solutions was analyzed spectro-photometrically at
$510 \mathrm{~nm}$ microplate reader (Epoch, Biotek Instruments, INC., VT, USA). The $\beta$-glucan content was calculated by subtracting the $\alpha$-glucan content from the total glucan content. These calculations can be simplified by using the Megazyme Mega-Calc ${ }^{\mathrm{Tm}}$. The $\beta$-glucan content was expressed as $\mathrm{g} / 100 \mathrm{~g}$ of mushroom dry weight.

\section{The quantitative analysis of cordycepin in GRC-ON89A}

The content of cordycepin was determined by UPLC quantitative analysis of GRC-ON89A, as the previously described methods [24]. The UPLC-Q-TOF-MS analysis were performed on a Waters Micromass Q-TOF Premier with a UPLC Acquity system (Waters Corp., Milford, MA, USA) equipped with a binary solvent delivery system, an auto-sampler, and UV (Ultraviolet Ray) detector. The separation was performed on an Acquity UPLC BEH C18 $(100 \mathrm{~mm} \times 2.1 \mathrm{~mm} \times 1.7 \mu \mathrm{m}$ particle size; Waters Corp.). UPLC-Q-TOF-MS analysis condition were as follows: injection volume $5 \mu \mathrm{l}$, flow rate $0.3 \mathrm{~m} / \mathrm{min}$, column temperature $37{ }^{\circ} \mathrm{C}$. The mobile phases consisted of $0.1 \%$ formic acid in water (solvent $\mathrm{A}$ ) and $0.1 \%$ formic acid in $\mathrm{ACN}$ (solvent B); the initial condition was $5 \% \mathrm{~B}$ for $1 \mathrm{~min}$, then $\mathrm{B}$ was gradually increased to $100 \%$ during $10 \mathrm{~min}$; the $100 \% \mathrm{~B}$ was maintained for $1 \mathrm{~min}$ and then decreased to $5 \% \mathrm{~B}$ during $3 \mathrm{~min}$. The total run time was $14 \mathrm{~min}$.

\section{Short chain fatty acid (SCFA) analysis}

SCFA was analyzed by Gas chromatography/Mass spectrometer (GC/MS, Agilent 7890B, Agilent Technologies, Inc., Santa Clara, CA, USA) at the Korea Basic Science Institute (Seoul, Korea, Western Seoul Center) as previously described [25].

\section{Statistical analysis}

Data are expressed as means \pm SEM or means \pm SD. Differences between groups were determined by one-way ANOVA (Analysis of variance) followed by Dunnett's ttest or Student's t-test. Statistical analysis was performed using SPSS, version 12 (SPSS Inc., Chicago, IL, USA).

\section{Results}

Screening GRC deposited at the ted by candidate probiotics for immune stimulatory activity

NO, released by macrophages, plays an important role in the innate immune response. NO levels are indirectly calculated by measuring the level of nitrites and nitrates. Among GRC extracts fermented with different probiotic strains, we screened out the one with the strongest immunostimulatory activity by measuring the level of NO produced by treated RAW 264.7 macrophages. The NO level released from GRC fermented with various probiotic stains (SC64, ON89A, Sal.Cla22) were compared with GRC alone. Among these, GRC-ON89A 
significantly increased NO production in RAW264.7 cells (Fig. 1a). The potential cytotoxicity of these samples on RAW 264.7 macrophages was investigated by measuring cell viability using a CCK-8 assay. All samples significantly increased RAW 264.7 cell viability (Fig. 1b). Therefore, we chose GRC-ON89A as the test extract for future immunoregulatory studies.

\section{GRC-ON89A increases phagocytic activity in RAW 264.7} and primary peritoneal macrophages

We investigated whether GRC-ON89A affected the phagocytic activity of RAW 264.7 macrophages and primary cultured peritoneal macrophages. GRC-ON89A significantly increased the phagocytic activity of RAW 264.7 cells (Fig. 2a) and primary cultured peritoneal macrophages (Fig. 2b) compared to non-treated control $(*=p<0.5, n>10)$ or GRC $(* *=p<0.01, n>10)$. GRCON89A-treated primary cultured peritoneal macrophages increased in size, compared to control and GRCtreated primary cultured peritoneal macrophages. This morphological change suggests that GRC-ON89A may induce primary peritoneal macrophage activity (Fig. $2 \mathrm{~b}$ ). No cytotoxic effects of GRC-ON89A were observed on primary peritoneal macrophages (Fig. 2c). These data demonstrate that GRC-ON89A was a stronger stimulator of phagocytic activity than GRC.
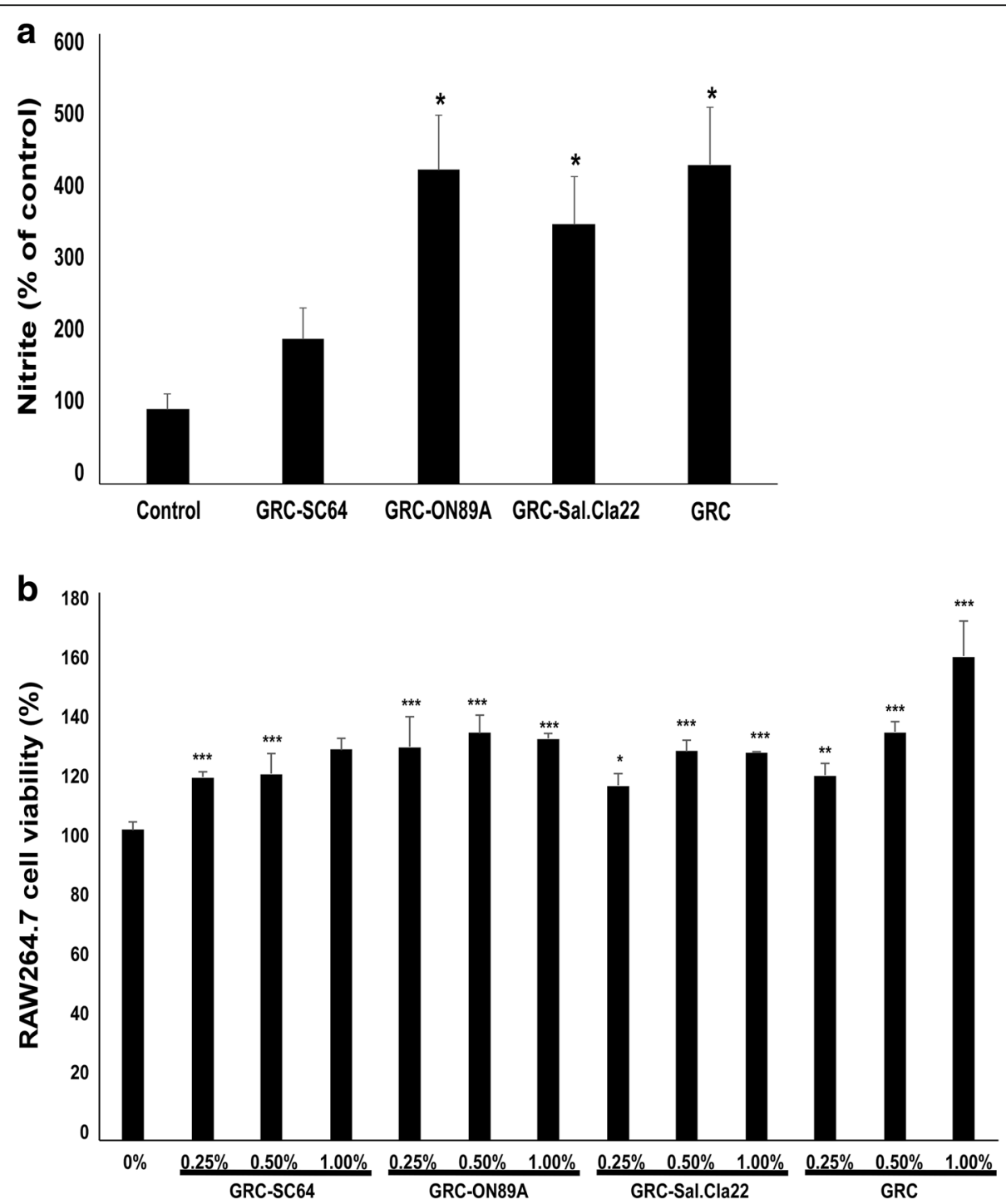

Fig. 1 Effects of GRC fermented with different probiotic stains on nitric oxide (NO) production. a RAW 264.7 cells were treated with GRC-SC64, GRC-ON89A, GRC-Sal.Cla22, or GRC. Nitrite levels in the culture media were determined using Griess reagent and were presumed to reflect NO levels. b RAW 264.7 cells were treated with various concentrations $(0.25 \%$, 0.50\%, and 1.00\%) of SC64, ON89A, Sal.Cla22, or GRC for 24 h. RAW 264.7 cell proliferation was assessed using a CCK-8 assay. One-way ANOVA was used for comparison of group means, followed by Dunnett's $t$-test $\left(^{*}=p<0.05,{ }^{* *}=p<0.01,{ }^{* * *}=p<0.005\right.$ vs. control group). Each figure is representative of three independent experiments 


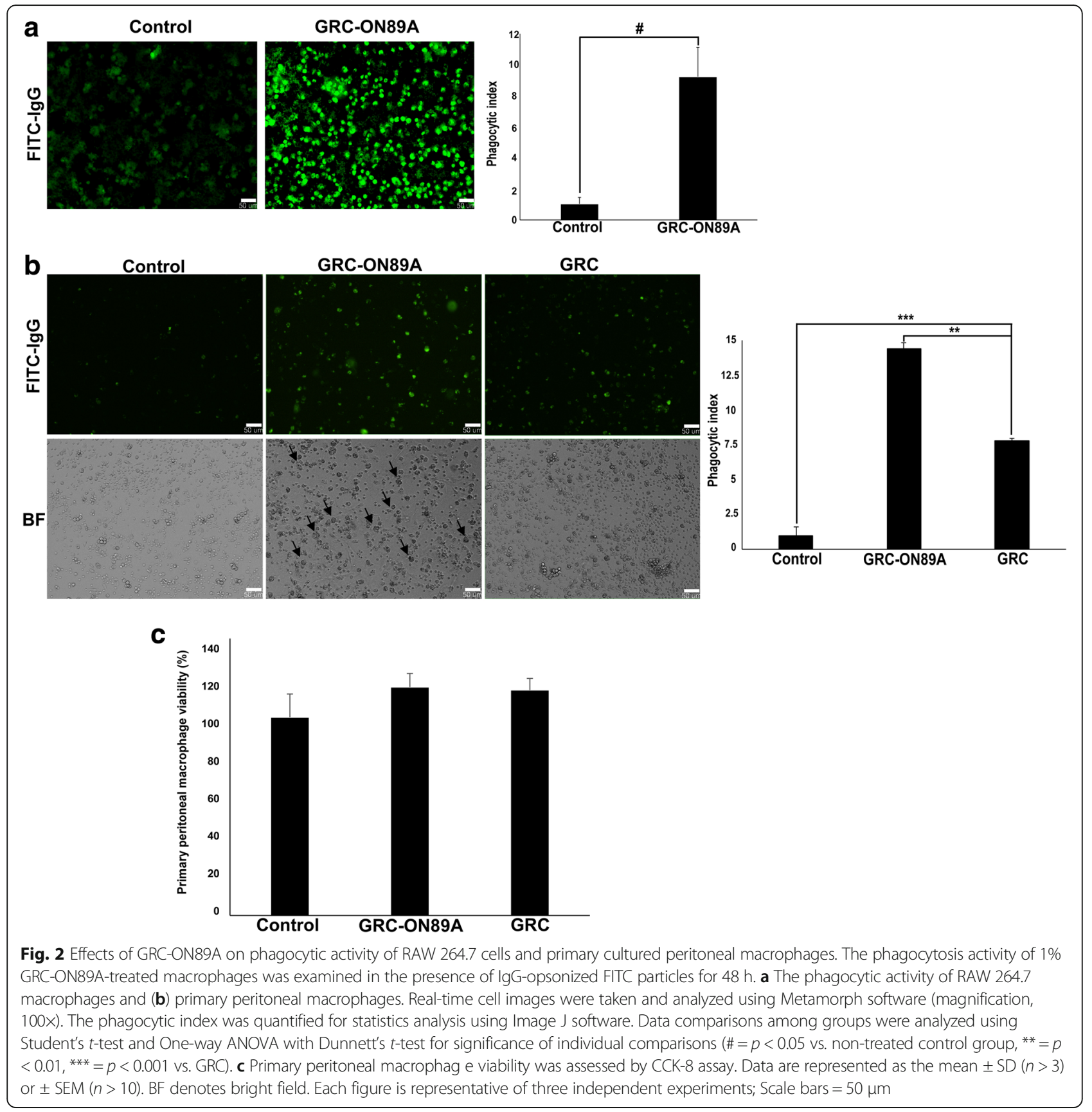

Effects of GRC-ON89A on phagocytic activity of peritoneal macrophages from CY-treated immunosuppressed mice and normal mice

The phagocytic activity of peritoneal macrophages from GRC-ON89A was assessed using IgG-opsonized FITC particles in immunosuppressed (Fig.3a) and normal (Fig.4a) murine models. Macrophage phagocytic activity decreased significantly after CY treatment. As shown Fig. 3b, GRC-ON89A significantly increased the phagocytic activity of peritoneal macrophages from CY-treated mice compared to GRC $(*=p<0.05)$. However, there was no significance in the phagocytic activity of peritoneal macrophages from mice after oral administration of GRC-ON89A and GRC since the standard deviation among mice was too big (data not shown). In the CY-treated immunosuppressed model, the number of peritoneal macrophages in the GRCON89A administered group was found to be significantly increased compared to CY-treated and GRCtreated groups (Fig. 3c). Additionally, we observed that the phagocytic rate of peritoneal macrophages from normal mice after oral administration of GRC- 


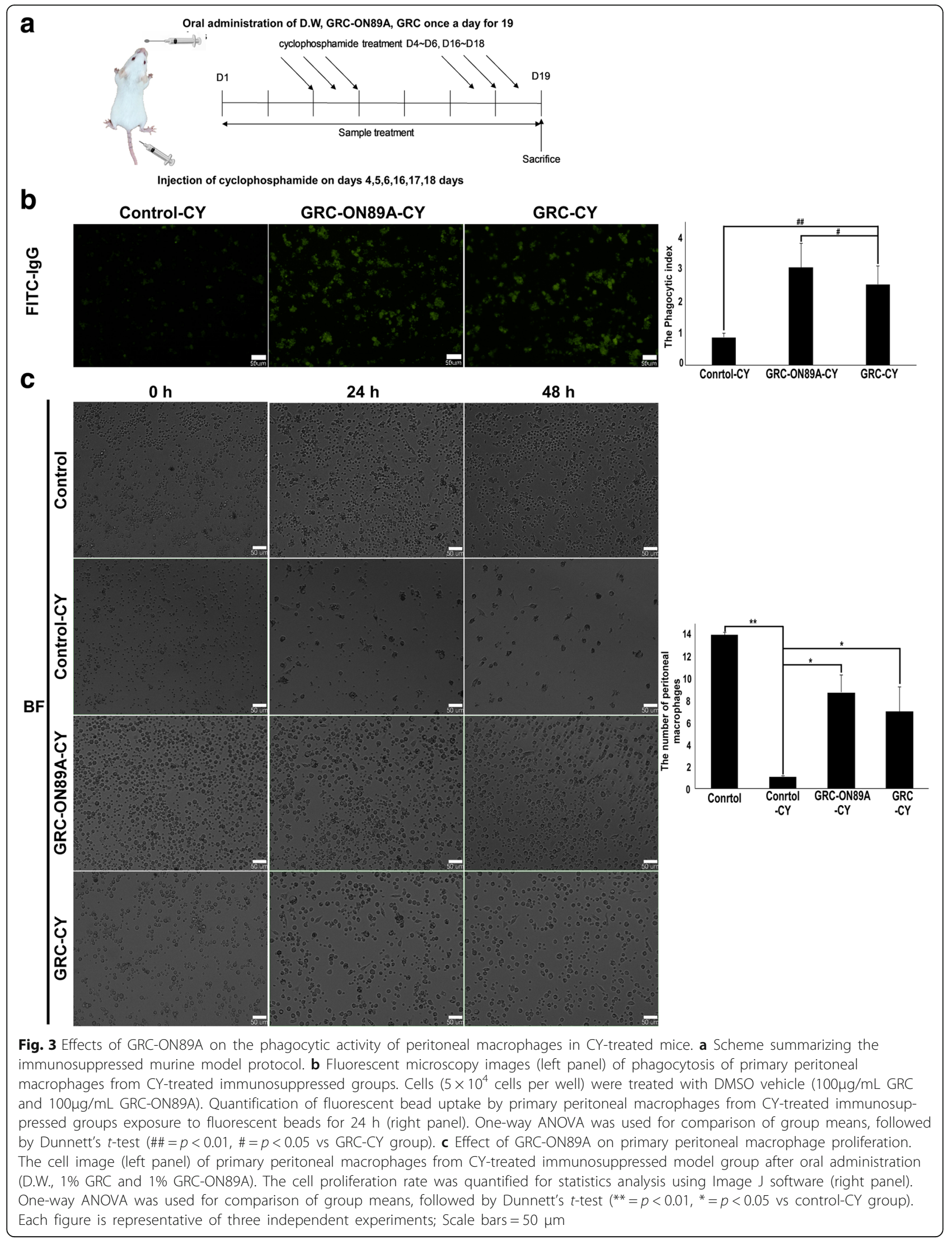




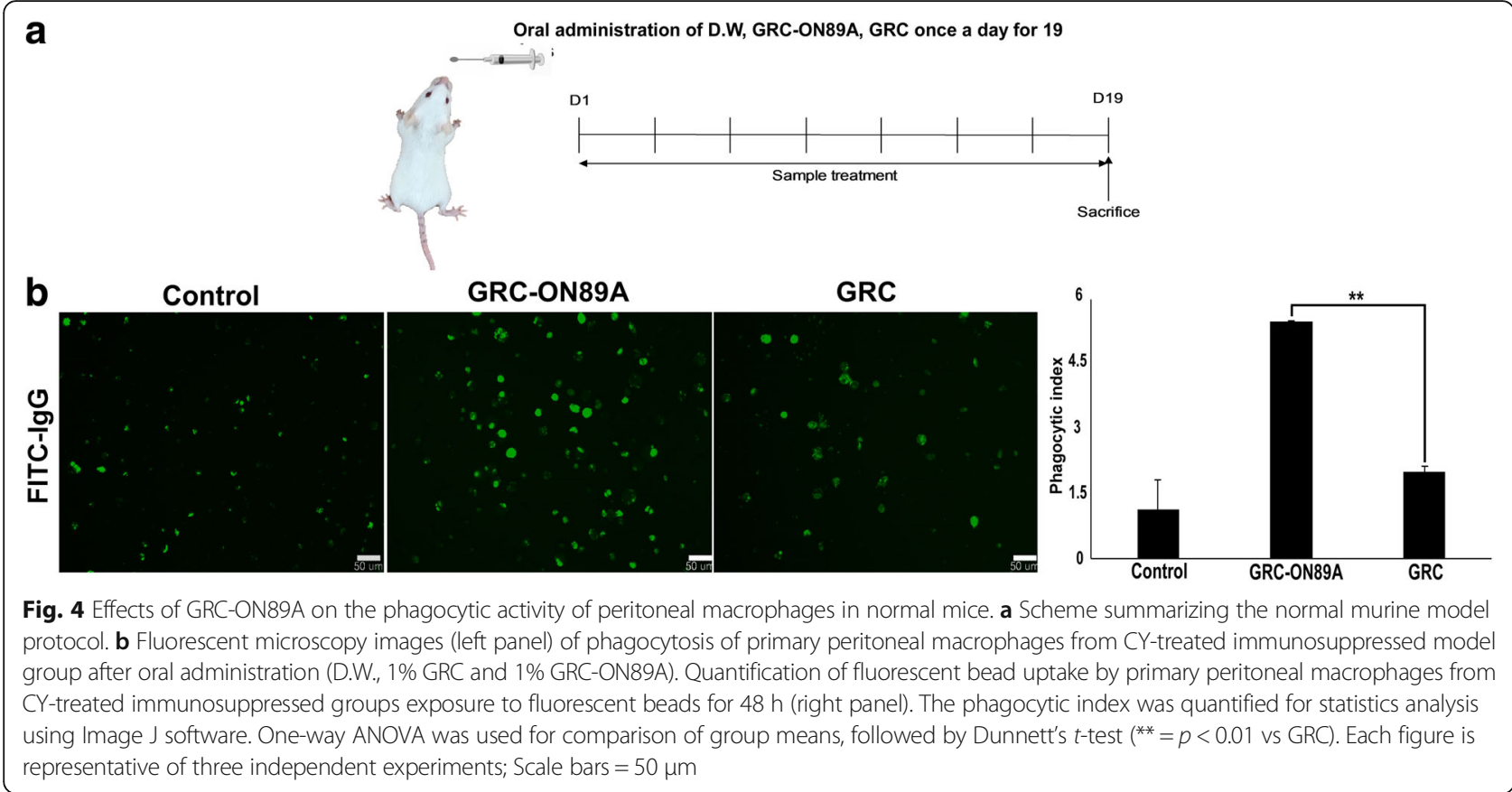

ON89A significantly increased compared to those from GRC (** $=p<0.01$, Fig. 4b).

Effects of GRC-ON89A on the phagocytosis related signaling molecules and on the levels of cytokine mRNA expression

To determine whether GRC-ON89A affects signaling pathways, we examined the level of phosphorylation in Lyn, Syk, and MAPKs. We observed increased phosphorylation of Lyn, Syk, and MAPKs after GRC-ON89A treatment in RAW264.7 cells $\left(* *=p<0.01,{ }^{* * * *}=p<\right.$ 0.001 vs non-treated control, Fig.5b). We observed nuclear translocation of $\mathrm{NFKB}$ and phosphorylation of $\mathrm{IkB}$ protein were increased and $\mathrm{I} \kappa \mathrm{B}$ protein was decreased. These results suggest that GRC-ON89A induces phagocytic activities by upregulating the activation of Lyn, Syk, MAPKs, and nuclear translocation of NFkB. Figure 5a illustrates a model detailing the role of GRC-ON89A in the phagocytic signaling pathways. GRC-ON89A treatment induced significantly higher TNF- $\alpha$ and IL-10 mRNA expression in RAW 264.7 cells $\left(^{*}=p<0.05\right.$ vs non-treated control, Fig. 5c).

Splenic and thymic indices of GRC-ON89A in normal and immunosuppressed mice

As shown in Table 3a, we found that splenic and thymic indices slightly increased in GRC-ON89A-treated groups compared to vehicle-treated and GRC-treated groups. In immunosuppressed mice (Table $3 \mathrm{~b}$ ), splenic and thymic indices slightly increased in GRC-ON89A-treated groups compared to vehicle-treated groups. ${ }^{* * *}=p<0.01$ vs CY treated group).

The content of bioactive compounds in GRC before and after fermentation with $P$. pentosaceus (ON89A)

To elucidate the enhanced immune activity of GRCON89A, we compared the content of several compounds in GRC before and after fermentation with ON89A. Our data indicated that $\beta$-glucan content of GRC and GRC-ON89A was $11.81 \pm 0.35 \mathrm{~g} / 100 \mathrm{~g}$ and $19.26 \pm 0.61 \mathrm{~g} / 100 \mathrm{~g}$, respectively (Table 1 ). The content of $\beta$-glucan in GRC-ON89A has higher than that in GRC. This result that ON89A might break down the high molecular weight of $\beta$-glucan from GRC. Next, we measured the content of cordycepin, known as a major component of C.miilitaris. A HPLC profile, including standard sample and GRCON89A, is shown in Fig. 6. The concentration of cordycepin from GRC-ON89A and GRC was $6.35 \pm$ $0.33 \mu \mathrm{g} / \mathrm{mg}$ and $10.44 \pm 0.46 \mu \mathrm{g} / \mathrm{mg}$, respectively (Fig. $6 \mathrm{~d})$. The content of cordycepin was increased in GRC-ON89A, compared to that in GRC. Our results are in agreement with other studies that an increase in acetic acid, propionic acid and lactic acid in GRC after ON89A fermentation. (Table 2). Our data showed that GRC-ON89A increased bioactive compounds compared to GRC. This result is consistent with the enhanced immune stimulatory activity in GRC-ON89A treated group, compared to GRC treated group. 


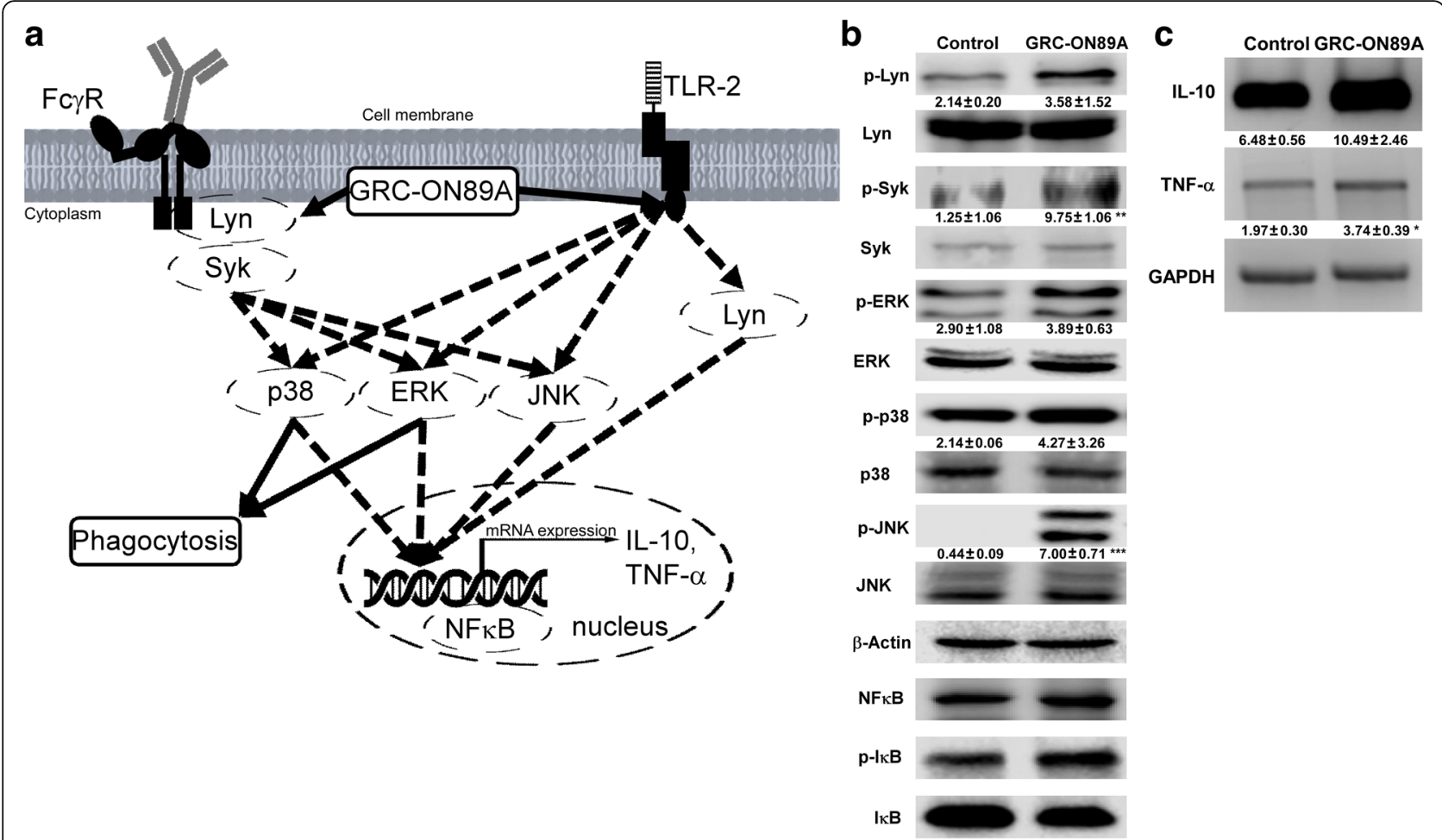

Fig. 5 The effect of GRC-ON89A on the phagocytosis related signaling molecules and on the levels of cytokine mRNA expression. a GRC-ON89A activated FcyR signaling pathway. RAW264.7 cells $\left(1 \times 10^{6} \mathrm{cell} / \mathrm{ml}\right)$ were treated with GRC-ON89A for $1 \mathrm{~h}$. b Total protein lysates were analyzed by Western blot analysis for phosphorylated - and total forms of Lyn, Syk, ERK, p38, JNK, NFKB, and IKB. $\beta$-Actin was used as the internal control. c The expression level of IL-10 and TNF-a mRNA in RAW 264.7 cells was determined by RT-PCR. Each figure is representative of three independent experiments. Data comparisons between groups were analyzed using Student's $t$-test and One-way ANOVA with Dunnett's $t$-test for significance of individual comparisons $\left(*=p<0.05,{ }^{* *}=p<0.01,{ }^{* *}=p<0.001\right.$ vs. control group)

The effect of bioactive compound in GRC-ON89A on macrophage activity

We checked the effect of $\beta$-glucan and GRC-ON89A on macrophages activity. The $\beta$-glucan-, GRC-ON89A- or LPS- treated RAW264.7 cells were increased in cellular size and numbers (Fig. $7 \mathrm{a}$ and b). In addition, the released amount of NO was increased in $\beta$-glucan treated RAW264.7 cells (Fig. 7c). These results suggest that the immuno-stimulatory effects of GRG-ON89A should be closely associated with the characteristic of $\beta$-glucan.

\section{Discussion}

The main objective of this study was to investigate the immunostimulatory effects of GRC fermented with Pediococcus pentosaceus. There is growing interest in

Table $1 \beta$-glucan content in the GRC-ON89A and GRC

\begin{tabular}{llll}
\hline Sample & Total glucan & a-glucan & $\beta$-glucan \\
\hline GRC-ON89A & $24.64 \pm 0.91^{\mathrm{A}}$ & $5.38 \pm 0.30^{\mathrm{A}}$ & $19.26 \pm 0.61^{\mathrm{B}}$ \\
GRC & $19.67 \pm 0.24$ & $7.86 \pm 0.14$ & $11.81 \pm 0.35$
\end{tabular}

All values are expressed as mean \pm SD. of triplicate measurements $\left({ }^{A}=p<0.05\right.$, ${ }^{\mathrm{B}}=p<0.005$ vs. GRC, $n>3$ ) identifying plant- or probiotic-originated immunomodulators for prophylactic and therapeutic purposes [26]. The general most commonly used in probiotic applications are Lactobacillus, Pediococcus, Weissella, Streptococcus, and Bifidobacterium. GRC fermentation differs with regard to various probiotic strains and was evaluated for its impact on immune regulatory activities. In this study, we demonstrated the immunostimulatory activities of GRC fermented with ON89A, including its macrophage-activating and immune function-enhancing properties in a normal mouse model. CY is often used in chemotherapy and organ transplantation [27]. One of main side effects of CY treatment is an immunosuppressive effect caused by damaged DNA in normal cells. Thereby, we also investigated the protective effects of GRC-ON89A in a CY-induced immunosuppressed mouse model. Macrophages exist in almost all tissues and regulate both innate and adaptive immunity [28]. They are derived from peripheral blood monocytes and present antigens to other immune cells via phagocytic activity. Activated macrophages produce great amounts of reactive oxygen/nitrogen species, as well as several cytokines, which contribute to the killing of bacteria- or 


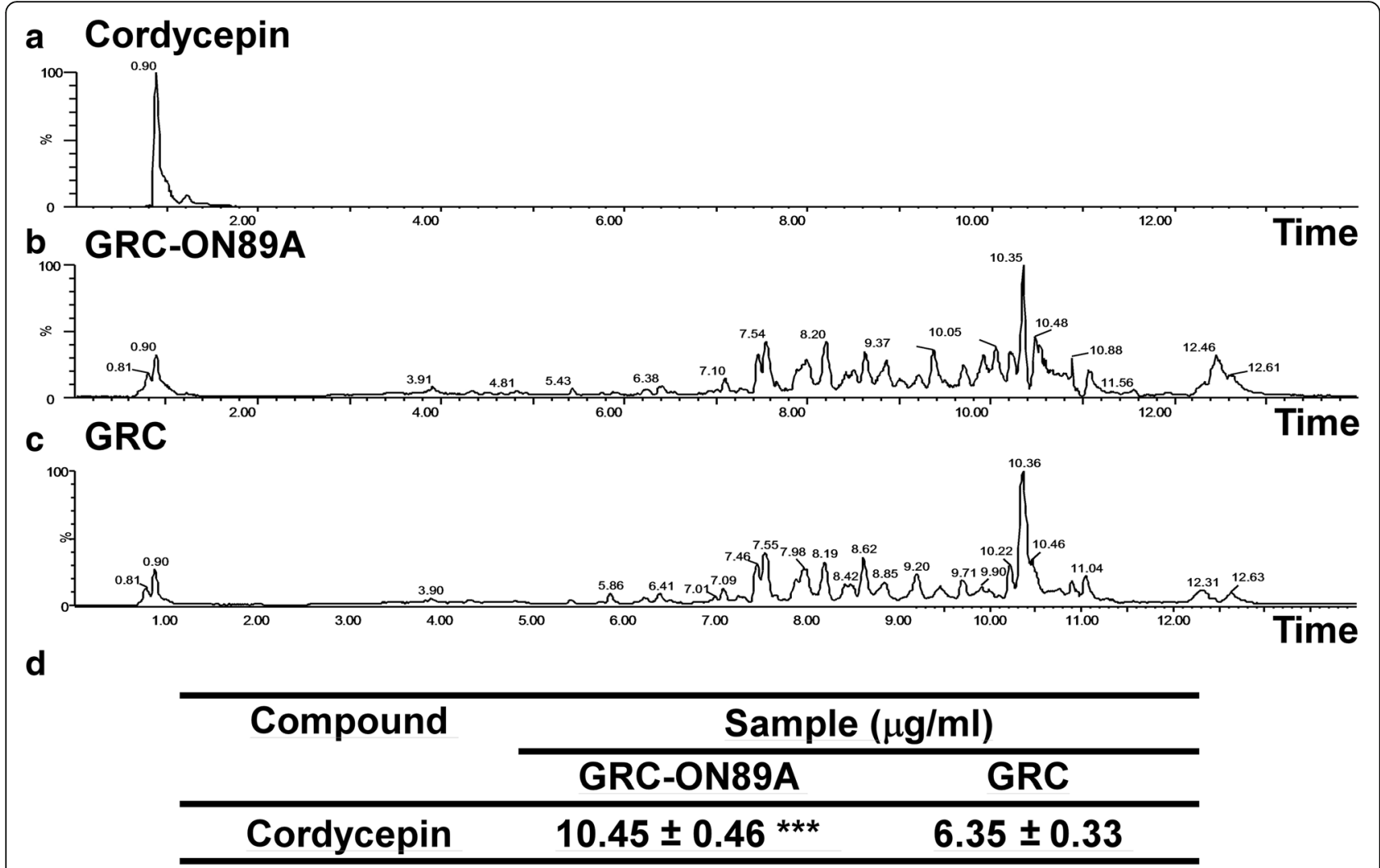

Fig. 6 Characterization of cordycepin content by UPLC-Q-TOF-MS. UPLC-MS chromatograms of (a) cordycepin, (b) GRC-ON89A and (c) GRC. d The quantitative analysis of cordycepin content in GRC before and after fermentation with ON89A. ${ }^{* * *}=p<0.005$ vs. GRC, $\left.n>3\right)$

virus-infected cells and tumor cells [29]. To identify the most active probiotic-fermented GRC sample, we examined NO release. Among the investigated samples, GRC-ON89A induced the greatest NO production (Fig. 1a). Thus, the immunological effects of GRC-ON89A were evaluated in this study.

$\mathrm{NO}$ is known to regulate the production of cytokines, such as TNF- $\alpha$, by macrophages and T lymphocytes [30]. Activated macrophages are associated with cytokines such as interferon- $\gamma$, IL-1 $\beta$, IL- 6, IL-10 and TNF- $\alpha$ to recruit and activate other cells for the initiation of the adaptive immune response [31, 32] GRC-ON89A has been shown to significantly induce TNF- $\alpha$ and IL-10 production in RAW 264.7 cells (Fig. 5c).

Table 2 The SCFA (acetic acid, propionic acid, lactic acid) content in GRC-ON89A and GRC

\begin{tabular}{lll}
\hline Compound & \multicolumn{2}{l}{ Sample $(\mu \mathrm{g} / \mathrm{ml})$} \\
\cline { 2 - 3 } & GRC-ON89A & GRC \\
\hline Acetic acid & 665 & 508 \\
Propionic acid & 1.9 & 0.2 \\
Lactic acid & 9155.5 & 8795.5 \\
\hline
\end{tabular}

The phagocytic function of macrophages is one of the most important non-specific immune responses against foreign organisms. Because phagocytosis by macrophages is the first immune response to invasive cells, including tumor cells and microorganisms, we investigated whether GRC-ON89A could enhance phagocytic activity. The phagocytic activity was monitored by detecting internalized IgG-opsonized FITC particles in macrophages and higher fluorescence emission intensity indicates increased phagocytosis activity. GRC-ON89A enhanced the phagocytic activity of RAW 264.7 cells (Fig. 2a), and primary peritoneal macrophages from normal mice (Fig. 2b). In addition, we evaluated whether GRC-ON89A could recover weakened immunity. CY suppressed the cell proliferation and the phagocytic activity of macrophages (Fig. 3b and c, left panel), which was consistent with previous studies [33, 34]. GRCON89A enhanced the phagocytosis of primary peritoneal macrophages from immunosuppressed (Fig. 3b) and normal mice (Fig. 4b) as measured by the quantification of fluorescent latex bead uptake. The oral administration of GRC-ON89A significantly increased the proliferation of peritoneal macrophages in immunosuppressed mice (Fig. 3c). The present study suggests that GRC-ON89A 
a
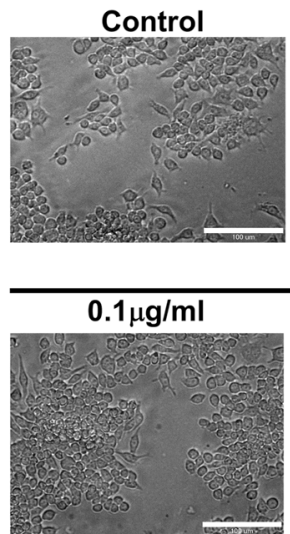

b

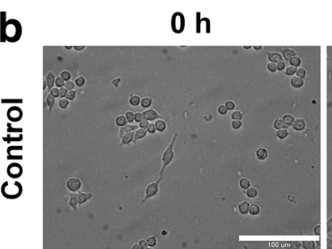

$24 \mathrm{~h}$

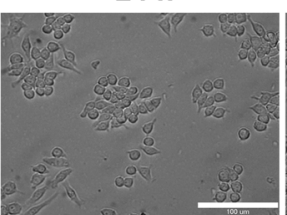

$\varangle$
o
ò
0
0
0
0
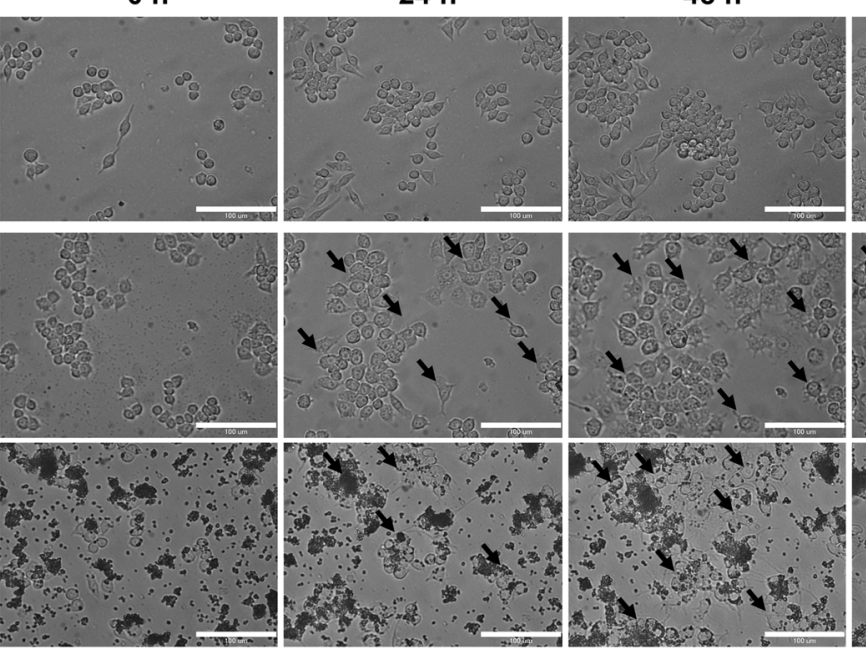

$72 \mathrm{~h}$
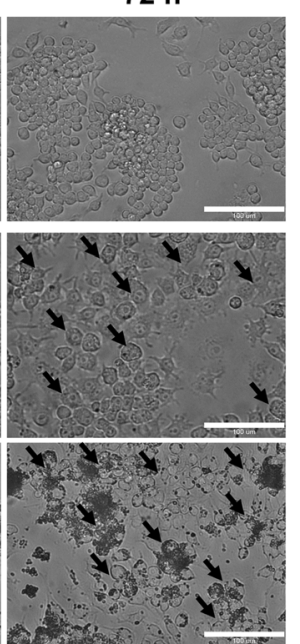

C

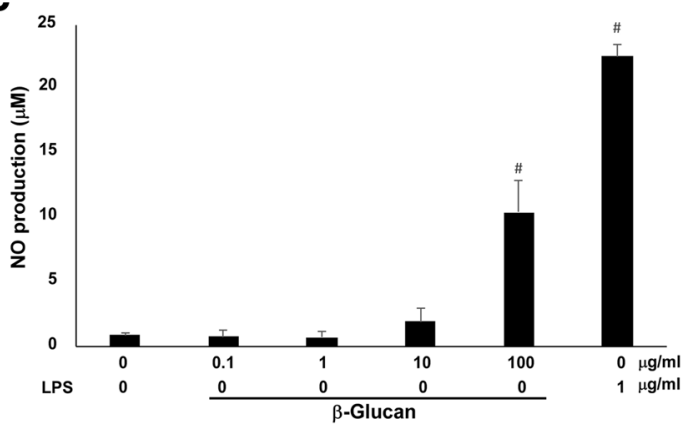

Fig. 7 Effect of GRC-ON89A and $\beta$-glucan on macrophage activity and morphology. a Cell morphological changes of $\beta$-glucan or GRC-ON89A treated RAW 264.7 cells. RAW 264.7 cells were treated with GRC-ON89A, $\beta$-glucan $(0.1,1,10,100 \mu \mathrm{g} / \mathrm{ml})$ or LPS (1 $\mu \mathrm{g} / \mathrm{ml})$. Arrows mediated RAW264.7 cells with increased cellular size. b The cell morphology of RAW 264.7 by GRC-ON89A, $\beta$-glucan (100 $\mu \mathrm{g} / \mathrm{ml})$ for 0, 24, 48, and $72 \mathrm{~h}$ was observed using Metamorph software for real time imaging (magnification, 200x). Arrows mediated RAW 264.7 cells with increased cellular size. $\mathbf{c}$ The level of NO production in RAW 264.7 cells by $\beta$-glucan. One-way ANOVA was used for comparison of group means, followed by Dunnett's t-test ( ${ }^{\#}=p<0.005$ vs. control group). Each figure is representative of three independent experiments; Scale bars $=100 \mu \mathrm{m}$

could enhance non-specific immune function in both immunosuppressed mice and normal mice.

Several studies have shown that Lyn is important in regulating phagocytic activity through recruiting autophagic components to the phagosome [21].
Eradicating Lyn hinders bacteria delivery to lysosomes [35]. Our data reveals that GRC-ON89A induced the phosphorylation of Lyn (Fig. 5). This finding indicated that GRC-ON89A facilitates phagocytic activity through the activation of Lyn, which acts as a link 
between phagosomes and autophagosomes. The major signaling pathways that lead to enhance phagocytic activities in macrophages include the $\mathrm{Fc \gamma} R$ pathway, Toll like receptor-2 (TLR-2) pathway, and others. As Src family kinases are important in Fc $\gamma \mathrm{R}$ signaling, Fc $\gamma$ R-mediated phagocytosis is defective in Lyn deficient macrophages in Lyn [36]. Previous studies have found that Syk plays an essential role in phagocytic receptor (i.e. Fc $\gamma R$ ) signaling [37]. In accordance with previous reports, we observed that phosphorylation of Syk was increased in the GRC-ON89A possesses immune regulatory activity.

Previous studies demonstrated that ERK and p38 MAPK play a key role in macrophage activation and phagocytosis [38, 39]. Activated ERK and p38 MAPK enhance actin polymerization, which is necessary for bacteria internalization by phagocytic activity of macrophages $[39,40]$. In addition, it is reported that MAPK activation induces IL-10 production in murine activated macrophages [41]. Furthermore, ERK, p38 MAPK and c-Jun N-terminal kinase (JNK) signaling pathway are activated by FcyRIIa [7]. MAPK and NFKB regulate gene expression of NO and TNF$\alpha$ that acts on innate immune response [42]. It is reported that $\mathrm{NF} \kappa \mathrm{B}$ is a role transcription factor in innate immunity [7]. Inhibitory I $\mathrm{B}$ proteins block the nuclear translocation of $N F \kappa B$ dimers. Upon stimulus, IкB kinase (IKK) phosphorylates IkB, which results in its degradation, and release NFKB for nuclear translocation [43]. Activated ERK mediates NFKB activation and also enhanced phagocytosis [44]. In this study, GRC-ON89A increased MAPK phosphorylation and $\mathrm{NF \kappa B}$ activation. These results suggest that GRC-ON89A may increase macrophage phagocytic activity through activation of the MAPK and Lyn pathways (Fig. 5). In addition, GRC-ON89A suppressed NO and pro-inflammatory cytokine production in LPS-stimulated macrophages (manuscript in preparation). It is likely that GRC-ON89A regulated both anti-inflammatory and phagocytic activities of macrophages.

Spleen and thymus are the major immune organs where the lymphocytes get matured and differentiated. Among lymphocytes, T cells and B cells are important effector cells in cell-mediated immunity [45]. It is reported that cyclophosphamide suppressed $\mathrm{T}$ lymphocyte proliferation and B-lymphocyte proliferation [46]. When GRC-ON89A was orally administered daily in normal and immunosuppressed murine models, GRC-ON89A treated group showed the increased weight of immune organs, such as the spleen and thymus (Table 3). We plan to study the effect of GRC-ON89A on the lymphocyte function and its mechanism of action in future.
Table 3 Effects of GRC-ON89A on immune organs

\begin{tabular}{llll}
\hline Group & $\begin{array}{l}\text { Number of } \\
\text { animals }\end{array}$ & $\begin{array}{l}\text { Splenic index } \\
\text { (SI) }\end{array}$ & $\begin{array}{l}\text { Thymic index } \\
\text { (TI) }\end{array}$ \\
\hline (A) & 10 & $0.36 \pm 0.01$ & $0.30 \pm 0.04$ \\
Con & 10 & $0.46 \pm 0.11$ & $0.35 \pm 0.04$ \\
GRC-ON89A & 10 & $0.37 \pm 0.02$ & $0.32 \pm 0.10$ \\
GRC & & & \\
(B) & 10 & $0.22 \pm 0.03$ & $0.13 \pm 0.04$ \\
Con-CY & 10 & $0.25 \pm 0.02 *$ & $0.28 \pm 0.04 * *$ \\
GRC-ON89A-CY & 10 & $0.27 \pm 0.06$ & $0.24 \pm 0.05 *$ \\
GRC-CY & 10
\end{tabular}

The splenic and thymic indices in (A) normal and (B) immunosuppressed mice. GRC-ON89A was administered daily from day 1 to 19 . The control group mice were treated with D.W. The data are presented as the mean \pm SEM $(n>10)$. Data were analyzed using the student $t$-test or One-way ANOVA with Dunnett's $t$-test ${ }^{* *}=p<0.01,{ }^{*}=p<0.05$ vs control-CY group)

We found there was a change in the content of bioactive compounds in GRC after ON89A fermentation. Several groups reported that $(1,3)-\beta$-D-glucan stimulated macrophage activation [47]. When high molecular weight $\beta$-glucan orally administered, it internalized and fragmented in the macrophages after entering the small intestine. These small $\beta$-glucan fragments, released from the macrophages, are taken up by other immune cells, which induce variety of immune responses [48]. In this study, we found that the $\beta$-glucan content of GRCON89A was higher than that of GRC (Table 1). The $\beta$ glucan treated RAW264.7 cells increased cell size and NO production (Fig. 7). This suggested that ON89A might have fragmented $\beta$-glucan from GRC, not newly producing $\beta$-glucan, which might enhance the immune responses in vitro and in vivo. It is reported that SCFA enhances innate immunity as a strong inducer of antimicrobial host defense peptides [49, 50]. Bacterial fermentation of indigestible carbohydrates in the intestine produced the major species of SCFAs, including acetate, propionate, and butyrate [51]. We found that the level of SCFA increased after fermentation with lactic acid bacteria ON89A (Table 2).

Previous studies demonstrated that cordycepin, initially isolated from Cordyceps, has many pharmacological activities, including immunostimulatory, anti-cancer and anti-infection activities [52]. Our analytical data indicated the content of cordycepin in GRC increased after fermentation by lactic acid bacteria ON89A (Fig. 6). Altered immune activity of macrophages may be due to the increased content of bioactive materials such as cordycepin in GRC-ON89A. We will persue potential bioactive compounds that are biotransformed after fermentation. In further studies, it would be worth performing the efficacy test through clinical study and immune deficient or cancer-xenograft animal models. 


\section{Conclusions}

The results demonstrated that GRC-ON89A could play an ethnopharmacologic role as an immune-stimulant. This study suggests that GRC-ON89A acts as an immune-stimulant in both CY-treated mice and normal mice by enhancing the phagocytic activity of mouse peritoneal macrophages and stimulating $\mathrm{NO}$ production in macrophages. It is likely that GRC-ON89A induced the phagocytic activity of macrophages through upregulating TLR-2 and FcyR-mediated signaling, such as tyrosine kinase Syk or other tyrosine-phosphorylated products. GRC after fermentation increased $\beta$-glucan, cordycepin and SCFA contents. Our data suggested that GRCON89A may be applied as an agent for immune boosting therapy in immune suppressed patients.

\section{Abbreviations}

ATCC: American type culture collection; CCK-8: Cell counting kit-8; CY: Cyclophosphamide; ELISA: Enzyme-linked immunosorbent assay; FBS: Fetal bovine serum; FITC: Fluorescein isothiocyanate; GAPDH: Glyceraldehyde 3-phosphate dehydrogenase; Gl: Gastrointestinal; GRC: C. militaris germinated rhynchosia nulubilis; IkB: Inhibitor of kappa B; IL: Interleukin; LAB: Lactic acid bacteria; LC: Liquid chromatography; Lyn: Lck yes novel; MAPK: Mitogen-activated protein kinases; MS: Mass spectrometry; NFkB: Nuclear factor kappa-light-chaine-enhancer of activated B cells; NO: Nitric oxide; PBS: Phosphate-buffered saline; PCR: Polymerase chain reaction; RNA: Ribonucleic acid; RT-PCR: Reverse transcription-polymerase chain reaction; SCFA: Short chain fatty acid; Syk: Spleen tyrosine kinase; TNF: Tumor necrosis factor; UPLC: Ultra Performance liquid chromatography

\section{Acknowledgements}

This work was supported by the technological convergence R\&D Program funded Korea Small and Medium Business Administration in 2016 (S2374296), and the National Research Foundation of Korea (NRF) grant funded by the Korea government (MSIP) (NO.NRF-2015R1C1A2A01051880). We, the authors, would like to thank Dr. Park and researchers from the Cell Activation Research Institute (CARI, Gyeonggi-do, Korea). The authors report no conflict of interest. The authors are responsible for the content and writing of this paper.

\section{Funding}

This work was supported by the National Research Foundation of Korea (NRF) grant funded by the Korea government (MSIP) (NO.NRF-

2015R1C1A2A01051880). We, the authors, would like to thank Dr. Park and researchers from the Cell Activation Research Institute (CARI, Gyeonggi-do, Korea). The authors report no conflict of interest. The authors are responsible for the content and writing of this paper.

\section{Availability of data and materials}

The supporting materials can be obtained upon request via email to the corresponding author.

\section{Authors' contributions}

HKK and WRJ contributed towards data analysis, manuscript writing and laboratory experiments. HJP made contributions to manuscript writing, acquisition of data, interpretation of data and design of experiments. All authors read and approved the final manuscript.

\section{Ethics approval}

All researchers on the animal studies were complied with the standards for the care and use of experimental animals. All of the animal experiments were performed in accordance to the instructions of the Medical Ethics Committee for the Use of Experimental Animals at Gachon University (GIACUC-R2015014)

\section{Consent for publication}

Not applicable

\section{Competing interests}

The authors declare that they have no competing interests.

\section{Publisher's note}

Springer Nature remains neutral with regard to jurisdictional claims in published maps and institutional affiliations.

Received: 17 August 2017 Accepted: 8 February 2018

Published online: 23 February 2018

\section{References}

1. Hackett CJ. Innate immune activation as a broad-spectrum biodefense strategy: prospects and research challenges. J Allergy Clin Immun. 2003; 112(4):686-94

2. Abdel-Hafez SMN, Rifaai RA, Abdelzaher WY. Possible protective effect of royal jelly against cyclophosphamide induced prostatic damage in male albino rats; a biochemical, histological and immuno-histo-chemical study. Biomedicine \& pharmacotherapy = Biomedecine \& pharmacotherapie. 2017; 90:15-23.

3. Alexandrova EM, Xu SL, Moll UM. Ganetespib synergizes with cyclophosphamide to improve survival of mice with autochthonous tumors in a mutant p53-dependent manner. Cell Death Dis. 2017;8(3):e2683.

4. Lori JC, Stein TJ, Thamm DH. Doxorubicin and cyclophosphamide for the treatment of canine lymphoma: a randomized, placebo-controlled study. Vet Comp Oncol. 2010;8(3):188-95.

5. Kumar VP, Venkatesh YP. Alleviation of cyclophosphamide-induced immunosuppression in Wistar rats by onion lectin (Allium Cepa agglutinin). J Ethnopharmacol. 2016;186:280-8.

6. Ren Z, He C, Fan Y, Guo L, Si H, Wang Y, Shi Z, Zhang H. Immunoenhancement effects of ethanol extract from Cyrtomium Macrophyllum (Makino) Tagawa on cyclophosphamide-induced immunosuppression in BALB/C mice. J Ethnopharmacol. 2014;155(1):769-75.

7. Yu Q, Nie SP, Wang JQ, Huang DF, Li WJ, Xie MY. Molecular mechanism underlying chemoprotective effects of Ganoderma atrurn polysaccharide in cyclophosphamide-induced immunosuppressed mice. J Funct Foods. 2015;15:52-60.

8. Park HJ, Han ES, Park DK, Lee C, Lee KW. An extract of Phellinus linteus grown on germinated brown rice inhibits inflammation markers in RAW264.7 macrophages by suppressing inflammatory cytokines, chemokines, and mediators and up-regulating antioxidant activity. J Med Food. 2010;13(6):1468-77.

9. Lee HH, Lee S, Lee K, Shin YS, Kang H, Cho H. Anti-cancer effect of Cordyceps militaris in human colorectal carcinoma RKO cells via cell cycle arrest and mitochondrial apoptosis. Daru. 2015;23:35.

10. Ryu E, Son M, Lee M, Lee K, Cho JY, Cho S, Lee SK, Lee YM, Cho H, Sung $\mathrm{GH}$, et al. Cordycepin is a novel chemical suppressor of Epstein-Barr virus replication. Oncoscience. 2014;1(12):866-81.

11. Patel S, Goyal A. Recent developments in mushrooms as anti-cancer therapeutics: a review. 3 Biotech. 2012;2(1):1-15.

12. Lee EJ, Kim WJ, Moon SK. Cordycepin suppresses TNF-alpha-induced invasion, migration and matrix metalloproteinase-9 expression in human bladder cancer cells. Phytotherapy research : PTR. 2010;24(12):1755-61.

13. Wang D, Zhang Y, Lu J, Wang Y, Wang J, Meng Q, Lee RJ, Wang D, Teng L. Cordycepin, a natural antineoplastic agent, induces apoptosis of breast cancer cells via caspase-dependent pathways. Nat Prod Commun. 2016; 11(1):63-8.

14. Park DK, Park HJ. Ethanol extract of Cordyceps militaris grown on germinated soybeans attenuates dextran-sodium-sulfate- (DSS-) induced colitis by suppressing the expression of matrix metalloproteinases and inflammatory mediators. Biomed Res Int. 2013;2013:102918.

15. Park DK, Choi WS, Park HJ. Antiallergic activity of novel isoflavone methylglycosides from Cordyceps militaris grown on germinated soybeans in antigen-stimulated mast cells. J Agric Food Chem. 2012;60(9):2309-15.

16. Ohta Y, Lee JB, Hayashi K, Fujita A, Park DK, Hayashi T. In vivo anti-influenza virus activity of an immunomodulatory acidic polysaccharide isolated from Cordyceps militaris grown on germinated soybeans. J Agric Food Chem. 2007:55(25):10194-9.

17. Goulet O. Potential role of the intestinal microbiota in programming health and disease. Nutr Rev. 2015;73:32-40.

18. Choi YJ, Yang HS, Jo JH, Lee SC, Park TY, Choi BS, Seo KS, Huh CK. Antiamnesic effect of fermented Ganoderma lucidum water extracts by lactic 
acid bacteria on scopolamine-induced memory impairment in rats. Preventive nutrition and food science. 2015;20(2):126-32.

19. Won TJ, Kim B, Song DS, Lim YT, Oh ES, Lee DI, Park ES, Min H, Park SY, Hwang KW. Modulation of Th1/Th2 balance by lactobacillus strains isolated from kimchi via stimulation of macrophage cell line J774A.1 in vitro. J Food Sci. 2011;76(2):H55-61.

20. Park HJ, Yang HJ, Kim KH, Kim SH. Aqueous extract of Orostachys japonicus a. Berger exerts immunostimulatory activity in RAW 264.7 macrophages. J Ethnopharmacol. 2015;170:210-7.

21. Liu Z, Xing J, Huang Y, Bo R, Zheng S, Luo L, Niu Y, Zhang Y, Hu Y, Liu J, et al. Activation effect of Ganoderma lucidum polysaccharides liposomes on murine peritoneal macrophages. Int J Biol Macromol. 2016;82:973-8.

22. Honarpisheh M, Foresto-Neto O, Desai J, Steiger S, Gomez LA, Popper B, Boor P, Anders HJ, Mulay SR. Phagocytosis of environmental or metabolic crystalline particles induces cytotoxicity by triggering necroptosis across a broad range of particle size and shape. Sci Rep. 2017;7(1):15523.

23. Zhang NN, Park DK, Park HJ. The inhibitory activity of atractylenolide capital SHA, Cyrillic, a sesquiterpenoid, on IgE-mediated mast cell activation and passive cutaneous anaphylaxis (PCA). J Ethnopharmacol. 2013;145(1):278-85.

24. Suh DH, Jung ES, Park HM, Kim SH, Lee S, Jo YH, Lee MK, Jung G, Do SG, Lee $\mathrm{CH}$. Comparison of metabolites variation and Antiobesity effects of fermented versus nonfermented mixtures of Cudrania Tricuspidata, Lonicera Caerulea, and soybean according to fermentation in vitro and in vivo. PLoS One. 2016;11(2):e0149022.

25. Moreau NM, Goupry SM, Antignac JP, Monteau FJ, Le Bizec BJ, Champ MM, Martin LJ, Dumon HJ. Simultaneous measurement of plasma concentrations and 13C-enrichment of short-chain fatty acids, lactic acid and ketone bodies by gas chromatography coupled to mass spectrometry. J Chromatogr B Analyt Technol Biomed Life Sci. 2003;784(2):395-403.

26. Ashraf $\mathrm{R}$, Shah NP. Immune system stimulation by probiotic microorganisms. Crit Rev Food Sci Nutr. 2014;54(7):938-56.

27. Mei YX, Chen HX, Zhang J, Zhang XD, Liang YX. Protective effect of chitooligosaccharides against cyclophosphamide-induced immunosuppression in mice. Int J Biol Macromol. 2013:62:330-5.

28. Weiss G, Schaible UE. Macrophage defense mechanisms against intracellular bacteria. Immunol Rev. 2015:264(1):182-203.

29. Shukla R, Goyal A. Novel dextran from Pediococcus pentosaceus CRAG3 isolated from fermented cucumber with anti-cancer properties. Int J Biol Macromol. 2013;62:352-7.

30. Bogdan C, Rollinghoff M, Diefenbach $A$. Reactive oxygen and reactive nitrogen intermediates in innate and specific immunity. Curr Opin Immunol. 2000;12(1):64-76.

31. Chung EY, Liu J, Homma Y, Zhang Y, Brendolan A, Saggese M, Han J, Silverstein R, Selleri L, Ma X. Interleukin-10 expression in macrophages during phagocytosis of apoptotic cells is mediated by homeodomain proteins Pbx1 and Prep-1. Immunity. 2007;27(6):952-64.

32. Karupiah G, Hunt NH, King NJ, Chaudhri G. NADPH oxidase, Nramp1 and nitric oxide synthase 2 in the host antimicrobial response. Reviews in immunogenetics. 2000;2(3):387-415

33. Jung JY, Shin JS, Lee SG, Rhee YK, Cho CW, Hong HD, Lee KT. Lactobacillus sakei K040706 evokes immunostimulatory effects on macrophages through TLR 2-mediated activation. Int Immunopharmacol. 2015;28(1):88-96.

34. Winkelstein A. Mechanisms of immunosuppression: effects of cyclophosphamide on cellular immunity. Blood. 1973;41(2):273-84.

35. Li X, He S, Zhou X, Ye Y, Tan S, Zhang S, Li R, Yu M, Jundt MC, Hidebrand A, et al. Lyn delivers bacteria to lysosomes for eradication through TLR2initiated autophagy related phagocytosis. PLoS Pathog. 2016;12(1):e1005363.

36. Fitzer-Attas CJ, Lowry M, Crowley MT, Finn AJ, Meng F, DeFranco AL, Lowell CA. Fcgamma receptor-mediated phagocytosis in macrophages lacking the Src family tyrosine kinases Hck, Fgr, and Lyn. J Exp Med. 2000;191(4):669-82.

37. Tohyama Y, Yamamura H. Protein tyrosine kinase, syk: a key player in phagocytic cells. J Biochem. 2009;145(3):267-73.

38. Ninkovic J, Roy S. Morphine decreases bacterial phagocytosis by inhibiting actin polymerization through CAMP-, Rac-1-, and p38 MAPK-dependent mechanisms. Am J Pathol. 2012;180(3):1068-79.

39. Luo Y, Pollard JW, Casadevall A. Fc gamma receptor cross-linking stimulates cell proliferation of macrophages via the ERK pathway. J Biol Chem. 2010; 285(6):4232-42.

40. Pfeiffer ZA, Aga M, Prabhu U, Watters JJ, Hall DJ, Bertics PJ. The nucleotide receptor $\mathrm{P} 2 \mathrm{X} 7$ mediates actin reorganization and membrane blebbing in
RAW 264.7 macrophages via p38 MAP kinase and rho. J Leukoc Biol. 2004; 75(6):1173-82.

41. Dobreva ZG, Miteva LD, Stanilova SA. The inhibition of JNK and p38 MAPKs downregulates IL-10 and differentially affects c-Jun gene expression in human monocytes. Immunopharmacol Immunotoxicol. 2009;31(2):195-201.

42. Shen $\mathrm{CY}$, Zhang $\mathrm{WL}$, Jiang JG. Immune-enhancing activity of polysaccharides from Hibiscus Sabdariffa Linn. Via MAPK and NF-kappa B signaling pathways in RAW264.7 cells. J Funct Foods. 2017;34:118-29.

43. Li Q, Lu Q, Bottero V, Estepa G, Morrison L, Mercurio F, Verma IM. Enhanced NF-kappaB activation and cellular function in macrophages lacking IkappaB kinase 1 (IKK1). Proc Natl Acad Sci U S A. 2005:102(35):12425-30.

44. Rosales C. Fcgamma receptor heterogeneity in leukocyte functional responses. Front Immunol. 2017:8:280.

45. Mosmann TR, Coffman R. TH1 and TH2 cells: different patterns of lymphokine secretion lead to different functional properties. Annu Rev Immunol. 1989;7(1):145-73.

46. Du XF, Jiang CZ, Wu CF, Won EK, Choung SY. Synergistic immunostimulating activity of pidotimod and red ginseng acidic polysaccharide against cyclophosphamide-induced immunosuppression. Arch Pharm Res. 2008;31(9):1153-9.

47. Akramiene D, Kondrotas A, Didziapetriene J, Kevelaitis E. Effects of betaglucans on the immune system. Medicina. 2007:43(8):597-606.

48. Han JY, Im J, Choi JN, Lee CH, Park HJ, Park DK, Yun CH, Han SH. Induction of IL-8 expression by Cordyceps militaris grown on germinated soybeans through lipid rafts formation and signaling pathways via ERK and JNK in A549 cells. J Ethnopharmacol. 2010;127(1):55-61.

49. Sunkara $L T$, Jiang WY, Zhang GL. Modulation of antimicrobial host defense peptide gene expression by free fatty acids. PLoS One. 2012;7(11)

50. Correa-Oliveira R, Fachi JL, Vieira A, Sato FT, Vinolo MA. Regulation of immune cell function by short-chain fatty acids. Clinical \& translational immunology. 2016;5(4):e73.

51. Zhong L, Zhang XF, Covasa M. Emerging roles of lactic acid bacteria in protection against colorectal cancer. World J Gastroentero. 2014; 20(24):7878-86

52. Shin S, Lee S, Kwon J, Moon S, Lee S, Lee CK, Cho K, Ha NJ, Kim K. Cordycepin suppresses expression of diabetes regulating genes by inhibition of lipopolysaccharide-induced inflammation in macrophages. Immune network. 2009;9(3):98-105.

\section{Submit your next manuscript to BioMed Central and we will help you at every step:}

- We accept pre-submission inquiries

- Our selector tool helps you to find the most relevant journal

- We provide round the clock customer support

- Convenient online submission

- Thorough peer review

- Inclusion in PubMed and all major indexing services

- Maximum visibility for your research

Submit your manuscript at www.biomedcentral.com/submit 